\title{
Diferentes gerações: Gênova, julho de 2001
}

\author{
ALESSANDRO PORTELLI*
}

\begin{abstract}
Resumo: Trata-se de depoimentos de pessoas que participaram da manifestação contrária à globalização, em Gênova, por ocasião da Reunião do G 8, em que se encontravam os líderes dos países mais ricos do mundo. Os depoentes, representantes de diferentes gerações, relatam as violências sofridas e as circunstâncias da morte do jovem estudante Carlo Giuliani, em julho de 2001. É destacada a participação de pais e filhos na referida manifestação - duas gerações, assim como a importância das novas tecnologias como diferentes modos de documentar os acontecimentos presenciados. Assim, o uso de telefones celulares, filmadoras e máquinas fotográficas, aliado ao relato dos acontecimentos, auxilia na reconstrução do que realmente aconteceu na cidade portuária, fatos que repercutiram por toda a Itália.
\end{abstract}

Abstract: Testimony of people who had participated in the manifesto against globalization, in Genoa, during the G 8 meeting, with the leaders of the world's richest nations. The deponents, representatives of different generations, had told about the violence, the suffering and about the circumstances that involved the death of the young student Carlo Giuliani, in July 2001. It emphasizes the participation of parents and children in the manifestations - two generations; as well as the importance of the new technologies as a way to register the witnessed events. Thus, the use of cellular telephones, filming and cameras, and the event's report, help in the reconstruction of what really happened in that city.

Palavras-chave: Protesto. Violência. Narrativas.

Key words: Protest. Violence. Narratives.

\footnotetext{
Tradução e notas do presente texto são da Profa. Dra. Núncia Santoro de Constantino, do PPGH-PUCRS. É texto inédito e resulta de projeto de pesquisa em que participam Francesca Pappalardo, Lorenza Parisi, Brunella Pinto, Susanna Trifiletti e Lalla Di Cerbo, sob a coordenação de Alessandro Portelli, através do Circolo Giani Bosio, de Roma. As gravações encontram-se depositadas no Archivio Sonoro Franco Coggiola, do referido Circolo.

* Professor na Universidade "La Sapienza", presidente do Circolo Gianni Bosio, de Roma.
}

Estudos Ibero-Americanos. PUCRS, v. XXXII, n. 1, p. 7-35, junho 2006 


\section{Orgulho e medo}

No dia 17 de julho de 2001, em Monterotondo, perto de Roma, um pai acompanha o filho à estação ferroviária. O filho é Bruno Lupi, que recém completou 18 anos e que está indo para Gênova, onde participará de manifestação de protesto, por ocasião da Reunião do G8. ${ }^{1}$ O pai, Antonino Lupi, é o prefeito de Monterotondo, eleito por uma coalisão de centro-esquerda. Planeja também viajar a Gênova no dia seguinte, com a delegação oficial do Conselho Comunal. ${ }^{2} \mathrm{Na}$ condição de prefeito, ao participar de uma manifestação pública, deverá portar a faixa com as cores da bandeira italiana e estará acompanhado por guardas municipais, um dos quais conduzindo o estandarte do município. Entretanto na véspera da sua partida, à noite, recebe um telefonema: seu filho Bruno fora preso.

Quando chega minha mulher penso, meu Deus, como contarlhe? De qualquer modo consegui contar e, no final das contas, fomos mais fortes do que imaginávamos; sobretudo minha mulher foi mais forte, demonstrando um temperamento diferente daquele que eu conhecia. Dada a notícia, em seguida, começamos a fazer os telefonemas necessários; conseguimos o número de um advogado do Forum Social, ${ }^{3}$ e logo fizemos contato com este advogado, combinando um encontro para a manhã do outro dia. Imaginávamos partir cedíssimo, mas, a uma hora da madrugada, minha mulher não suportava mais a espera e decidimos partir imediatamente, pois, de qualquer maneira, não era possível dormir. Não era possível dormir também porque, ao anoitecer, quando minha mulher chegava do trabalho, assistiu-se cena terrível na televisão: a morte de Carlo. Justo no momento em que minha mulher entrava em casa, sucedia o desastre: viu-se a imagem de Carlo que lembrava muito Bruno, pela sua constituição física e, de modo particular, pelo crâneo. Felizmente logo chegava uma primeira comunicação, afirmando ser o morto um espanhol. Logo depois chegava a notícia de que se tratava de um estudante romano e por isso tivemos um momento de... Bem, de tranqüilidade - tranqüilos pelo modo de dizer, porque não se tratava de Bruno. Mas aquela imagem, era impossível dormir com aquela imagem na cabeça, com a angústia de lembrar a situação dos pais que haviam perdido aquele filho; de qualquer mo-

1 Reunião de cúpula do grupo que reúne líderes dos sete países mais ricos e que também inclui a Rússia. Tais reuniões debatem os interesses do capitalismo globalizado.

2 O Consiglio Comunale exerce funções análogas à Câmara de Vereadores nos municípios brasileiros.

3 Trata-se do Forum Social Mundial, que se opõe ao neoliberalismo e a todas as formas de imperialismo. O primeiro encontro do FSM foi realizado em Porto Alegre, no ano de 2001. 
do, estávamos enfrentando uma situação de grande angústia. Estávamos sem cabeça, completamente sem cabeça, e naquela noite, como se não bastasse, haveria um espetáculo musical em Monterotondo. Quem era mesmo que se apresentava? - Tiromancino. Eu telefonei, pois deveria estar no palco; telefonei ao assessor Giganti, contando o sucedido. Neste meio tempo, dava-se o assassinato de Carlo, que foi comunicado de imediato.

Na verdade, num primeiro momento pensamos em suspender o concerto; depois decidimos taxativamente mantê-lo, porque, apesar de tudo, era preciso demonstrar que a vida continuava. Foram feitos os comunicados e houve também um momento de reflexão, do qual não participei por motivos óbvios. Partimos em torno da uma, uma e meia da madrugada.

Depois de quatro dias de frenéticos telefonemas e de buscas através de Gênova, Antonino Lupi e sua mulher, finalmente, conseguiram localizar o filho na penitenciária de Alessandria, para onde fora transferido junto com uma dúzia de outros manifestantes, depois de ter sido ilegalmente preso, espancado e torturado no quartel de Bolzaneto.

Bruno Lupi: Logo entrando em Bolzaneto recebemos as primeiras pancadas; eu fui o penúltimo a descer da camioneta e vi o desfile das pessoas que entravam e recebiam pancadas como se fossem as boas-vindas do quartel de Bolzaneto. Era como dizer: tomem cuidado, a situação é esta, prestem atenção. Cheguei de Gênova a Bolzaneto, distante a dez, quinze minutos, fazendo o trajeto com algemas muito apertadas nos pulsos, colocadas desde o momento da prisão; obviamente o sangue já não circulava mais. Passando com a camioneta da polícia, vi outros companheiros da manifestação que, do alto de um viaduto e vendo passar a camioneta com pessoas presas, levantavam o punho como saudação. E assim não me senti tão sozinho naquela camioneta, cercado de policiais; senti que lá fora o movimento continuava.

Em seqüência aos golpes de boas-vindas, logo à chegada, aconteceu aquilo que todos puderam ler nos jornais - fomos mantidos em pé, com as mãos na parede, durante todo o tempo em que estivemos no quartel, durante toda a noite. Era uma posição de tal forma difícil de manter que quase sentia-se alívio quando te tiravam dela por diversão. Então, empurravam-nos para o corredor, onde podiam bater mais livremente. Quase se preferia receber as pancadas do que ficar de pé. Havia alguns que não conseguiam permanecer naquela posição, sobretudo as pessoas mais velhas ou as que já haviam sido espancadas na praça ${ }^{4}$, ou ainda as que haviam sido

4 Refere-se à Praça Alimonda, onde a violência se generalizou e onde foi morto Carlo Giuliani. 
muito espancadas na entrada do quartel. Naturalmente, ficar de pé era um dever de todos, e quem não obedecesse sofria as conseqüências; a punição era a tortura, a verdadeira tortura, cujos métodos, lá em Bolzaneto, foram os mais variados, seja em mim, seja naqueles que pude ver à minha direita ou à esquerda, seja ainda por ouvir os gritos em torno. Éramos todos mantidos em grandes salas escuras, quatro em cada parede, me parece que eram cinco na parede onde eu estava; só éramos tirados daquela posição por algum motivo especial, como o simples divertimento de qualquer agente. Outro motivo era pelo fato de que precisávamos fazer nossa identificação, com as impressões digitais, a foto e, depois, precisávamos ainda fazer uma consulta médica. Naturalmente, o trajeto para alcançar os diversos lugares onde faríamos tais coisas era bastante tortuoso. Para ser identificado, apenas saindo da sala onde me encontrava, no fundo do quartel de Bolzaneto, precisei afastar-me do quartel e andar até o prédio ao lado; caminhei por todo o corredor que levava à saída, onde estavam enfileirados os Gom ${ }^{5}$ com suas botas e luvas; formavam duas filas, batiam com força e à vontade. Não se admite que fosse uma coisa casual os agentes estarem alinhados daquela maneira - outra razão não haveria, a não ser bater. $\mathrm{O}$ que estariam fazendo ali a não ser dar pancadas nos que passavam? ${ }^{6}$ Logo fui identificado e levado de volta à minha grande sala, refazendo o percurso, junto com os outros.

Logo que retornava da identificação, lembro que me pediram que renegasse os valores do antifascismo, gritando Viva il Duce. ${ }^{7} \mathrm{Fi}-$ quei um momento perplexo mas, em seguida e graças ao encorajamento de socos, disse aquilo que me obrigavam a dizer, já ingressando com esforço na cela; assim também fizeram os outros presos. Isto acabou por transformar-se em prática, quase como uma palavra de ordem, para que nos poupassem da tortura. Depois, ouvia-se canções fascistas; foi virando moda torturar as pessoas fazendo referência ao fascismo, ao fato de que o fascismo estaria retornando.

Ouvia-se a Faccetta nera, ouvi principalmente a Faccetta nera. ${ }^{8}$ Também ouvia-se vários slogans, como "boia chi molla", em suma, os slogans clássicos. Entre outras coisas, fomos levados para fora de Bolzaneto, com o braço direito levantado ${ }^{10}$; acredito que isso era imposto por um agente de posto superior, porque um outro, com quem eu falava, lhe disse "Não, não, deixa para lá", e este, o de pos-

5 Membros da polícia encarregados de coibir sublevações.

6 O entrevistado refere-se à técnica de tortura conhecida no Brasil como "corredor polonês".

Exigiam que fossem dados vivas a Benito Mussolini.

8 Canção muito popular, divulgada durante a invasão colonialista italiana na Etiópia, que promete "um outro Duce e um outro rei" à "bela Abissínia" (N. T.).

9 Slogan fascista dos anos setenta; é o mesmo que dizer "quem abandona a batalha é traidor".

10 Trata-se da conhecida saudação fascista. 
to superior, respondeu: "Cabo, anda e faz com que levante o braço". Aquele que estava sendo chamado de cabo me ordenou que levantasse o braço e que caminhasse; foi assim que saímos do quartel de Bolzaneto, com o braço direito levantado. ${ }^{11}$

Naquele dia, eu e minha mulher estávamos no carro, indo para o sul, com o rádio ligado e muita apreensão, porque também tínhamos um filho em Gênova. Aquilo que lá acontecia estava repercutindo por toda a Itália, através do rádio e do telefone celular, com ressonância entre diferentes gerações. Este fato, se não chegava a ser um fenômeno totalmente novo, era por certo e de modo particular, um fenômeno muito intenso. Os protagonistas de Gênova foram sobretudo jovens, muitos numa primeira experiência de manifestação (ainda que depois, nas ruas de Gênova, estivessem presentes todas as gerações). Muitos desses jovens possuíam raízes familiares em movimentos políticos ou com envolvimento político. Por isso, a atitude de muitas famílias era uma mistura de orgulho pelo compromisso dos filhos, aliada ao medo por aquilo que poderia acontecer em momentos de tensão e de confronto, momentos possíveis de prever.

Brunella Pinto. Quando da manifestação em Gênova, a coisa me envolveu muitíssimo - Papai, vou a Gênova. Disse meu pai: eu esperava por isso, devo te dizer a verdade, Brunella: eu sou teu pai e preferiria que não fosses porque receio pela tua segurança. Mas estou orgulhoso porque vais, e nunca direi que não deves ir. A coisa me provocará ataques de hipertensão, crises de psoríase e todas as doenças psicosomáticas que se manifestaram nos meus pais há cinqüenta anos, nestes cinqüenta anos em que assistiu-se à falência miserável de ideais e que se descobre a...

\section{Carlo Giuliani, ragazzo ${ }^{12}$}

11 Durante a entrevista com Bruno Lupi, também estava presente Enrico Angelani, que pertencia a uma antiga família antifascista di Monterotondo e que lembrou um episódio idêntico acontecido durante o período fascista. "O delito que imputavam ao meu tio era não ter ido trabalhar no Primeiro de Maio (de 1929), sem apresentar justificativa. Instaurou-se um processo em que ele foi obrigado a cantar e a dar vivas ao Duce, assim como a dizer que sua mulher, naquele Primeiro de Maio estava doente. Por isso foi absolvido".

12 Carlo Giuliani, um rapaz. 
O 20 de julho começou como uma festa. A passeata dos que chegavam a Gênova era momento de alegria, com gente que representava várias gerações.

Emanuele Profumi. A passeata era uma das mais bonitas de que participei, belíssima, havia todas as cores e alegria geral; havia diversidade cultural transpirando por todos os poros; via-se por lá um monge budista, vestido de modo estranho: - "Mas quem é? - "É um monge e tenho prazer que também esteja entre nós"; e via-se igualmente uma série de grupos de gente mais banal, comum, aquela gente que podemos ver sempre por aqui: senegaleses, marroquinos, paquistaneses. Foi uma passeata belíssima. Além do mais, houve todos aqueles reencontros. Por acaso encontrei um amigo de escola que está participando do Projeto Erasmus ${ }^{13}$ em Sevilha, na Espanha. Encontros muito bonitos, uma atmosfera diferente, na qual passeavam e discutiam tranqüilamente também os políticos. Uma praça em movimento, mudando de lugar.

Brunella Pinto. Tá bem! Na quinta-feira, a passeata dos que vinham de fora foi uma coisa grandiosa... Penso que, na verdade, foi um dos dias mais emocionantes da minha vida, porque nunca estivera junto com todos, o avô, o pai e o irmão... Sob o ponto de vista das gerações, havia grande satisfação e confirmação daquilo que se estava fazendo..., isto é, no sentido de que eu sou uma jovem rebelde de vinte anos, mas há também aqueles de cinqüenta anos mais rebeldes do que eu... Não sou louca, não sou diferente, há trezentas mil pessoas que se consideram diferentes como eu, daí que talvez os loucos sejam os outros. Começo a perceber as coisas de um outro ponto de vista. Via-se mães, crianças, via-se pessoas em cadeira de rodas, que depois seriam espancadas... é aquela outra face... a outra face daquilo que te impressiona.

No outro dia, enquanto suspeitos grupos de black bloc ${ }^{14}$ agiam enfurecidos pela cidade, sem que fossem perturbados, a polícia atacava as concentrações e as pacíficas passeatas, sem que houvesse provocação. A violência continuará em Bolzaneto e na Diaz ${ }^{15}$, culminando com a morte de Carlo Giuliani. Para muitos

13 Projeto Erasmus Mundus, iniciativa da União Européia para criar intercâmbio entre alunos, pesquisadores e docentes universitários.

14 Elementos pertencentes a grupos de inspiração anarquista, que se apresentam de preto e desenvolvem táticas de organização para protestos contra o capitalismo, o estado, contra a guerra, pregando, portanto, a desobediência civil. Praticam formas agressivas de luta e, em Gênova, destruíram carros e lojas, sem que a polícia impedisse.

15 Refere-se à Escola Diaz, um dos lugares em que dormiam os manifestantes e onde se localizava o Centro de Comunicação. Foi invadida durante a noite, bateram em todos os presentes e destruíram as instalações, deixando piso e paredes manchados de sangue. A polícia foi alvo de processo judicial. 
jovens representou um choque esta descoberta inesperada da violência do estado.

Gian pessoas em cadeira de rodas, que depois seriam espancadas... é aquela outra face... a outra face daquilo que te impressiona.

No outro dia, enquanto suspeitos grupos de black bloc agiam enfurecidos pela cidade, sem que fossem perturbados, a polícia atacava as concentrações e as pacíficas passeatas, sem que houvesse provocação. A violência continuará em Bolzaneto e na Diaz, culminando com a morte de Carlo Giuliani. Para muitos jovens representou um choque esta descoberta inesperada da violência do estado.

Gian. Podes imaginar como marca uma coisa deste gênero... Foi difícil.

Para alguns, o assassinato de Carlo Giuliani lembra anos passados: "retornou tudo aquilo que antes eu pensava e que, com o passar do tempo, coloquei à parte. Apesar de toda a minha cultura, da minha idade; retornou tudo como se eu ainda fosse uma moça de 18-20 anos, com raiva contra a polícia, digamos contra o poder constituído que havia espancado meu pai, que me havia espancado e que, em momentos assim, cruciais, ainda usa esses meios" (Pina Monaco) Mas, para a maior parte dos jovens que nem mesmo eram nascidos na última vez que a polícia matou na rua, é um trauma quase indescritível: "Perdemos a vingindade; isto é, o movimento que era mesmo muito ingênuo encontrou-se diante da crueldade do fato, do combate real. Nenhum de nós pensava que o nível do ataque militar, por parte do estado, pudesse chegar a este ponto" (Alessio Aringoli). "Falando com franqueza", disse um manifestante um pouco mais velho, "não é que não tenhamos considerado uma coisa deste tipo. Talvez isso não tenha sido considerado por quem veio a Gênova participando de uma manifestação pela primeira vez; mas nada indicava que a polícia fosse matar alguém, digamos assim. Desde muito tempo vínhamos sendo preparados politicamente, mas, sob o ponto de vista sentimental, penso que era uma geração completamente despreparada para aquilo que aconteceu" (Danilo Corradi). O trauma foi tamanho que faltam palavras para descrevê-lo: "também porque não falei com ninguém a fundo, nem mesmo aos meus amigos, porque não sabia como falar, era tudo muito estranho, um pouco era pelo choque" (Anna Carone).

Antonella Valentini. Chegou aquele rapaz desesperado, não sei se chegou da praça Alimonda; estava com o desespero nos olhos e dizia, aos gritos: "Mataram dois, mataram dois". Dizia isso procurando alcançar o palco. Foi assim que chegou a notícia da morte 
de Carlo, foi deste modo que chegou a notícia. A polícia em volta, os helicópteros sobre a nossa cabeça e aquele rapaz chorando. Recebemos um terrível golpe, nem mesmo sei explicar a sensação ao saber que havia gente morta.

Arianna Lodeserto. Que dizer? Foi uma coisa verdadeiramente aterrorizante, não há palavras para explicar... só lembro que vi na televisão, quando chegamos a Prato. Antes de ir a Gênova me pareceria absurdo e violento e terrível e basta... lembro que minha amiga e eu estávamos chocadas, tudo isto nos abalava muitíssimo. Eu estava com raiva e brigava com todo mundo. Porque não há razão para acontecer uma coisa do gênero. Lembro que me atingia muito, me desagradava ouvir contar sobre o rapaz morto, sobre aquilo que havia sido a sua vida, uma coisa... depois, de vez em quando, apareciam ainda outras notícias. A coisa mais grave foi o fato de procurarem razões para explicar aquilo como se fosse um ato de defesa ou um ato justificável. Seja como for, é absurdo e não deveria jamais ter acontecido. Seria necessário apenas ficar atônito e basta, sem buscar outras justificativas; foi por demais desumano. Foi uma coisa que me feriu, como se um caminhão tivesse passado por cima de mim, uma coisa alucinante...

Emanuele. Chovia e estávamos na arquibancada daquele estádio [Carlini] $]^{16}$ e não se podia sair porque alí estava a polícia, não tinhamos nada para comer, não tínhamos nada e diziam que a Protezione Civile ${ }^{17}$ traria algo para comer. Por fim, não sei como resolveram a questão da comida. Na verdade, presenciavam-se cenas no meio das poças de barro; as pessoas procuravam fazer escoar a água empoçada debaixo das barracas e, durante todo o tempo, fiquei sentado sobre os degraus da arquibancada e lembro que havia um rapaz ao meu lado que, quando falaram da morte de Carlo, irrompeu num choro convulso e dizia: "É o meu amigo Carlo Giuliani”... Eu não sei, chorei por vários dias, emagreci não sei quantos quilos e permaneci aterrorizado pelas forças da ordem, pela violência. ${ }^{18}$

16 Também havia manifestantes acampados no Estádio Carlini, na periferia de Gênova.

17 Protezione Civile é o conjunto de atividades organizadas para auxiliar em situações de perigo. É portanto uma organização de Estado análoga à Defesa Civil brasileira, cujo objetivo é reduzir calamidades, preparar para emergências e desastres, contando com a participação da comunidade.

18 O absurdo é reforçado, ao menos para alguns entrevistados, pelo fato de que o policial que matou Carlo Giuliani tinha a sua idade: "Na Puglia conhecia um rapaz que freqüentava o Liceu comigo e era carabiniere e no sul não se encontra trabalho; por fim, ele fez o curso de carabiniere, ele é de 80 como eu, e o enviaram a Genova. Ele estava do outro lado, fazendo parte das forças da ordem e daí comecei a falar com ele e permaneço chocada com esta experiência; ele ficou ali verdadeiramente muito mal, não queria falar... Eu desejava dizer: "mas que droga fizeste? Te dás conta de toda esta situação?" Daí que vejo este rapaz como uma vítima, pelo simples fato de que, na verdade, o que desejava era um trabalho, entendeu? Ele poderia ter arriscado tan- 
A Praça Alimonda foi rebatizada como "Piazza Carlo Giuliani, ragazzo". A palavra Ragazzo - rapaz, reinterpreta Carlo Giuliani como um símbolo de todos que estavam em Gênova naqueles dias. Principalmente simboliza o grupo dos mais jovens que, naqueles dias, defrontou-se pela primeira vez com a violência da polícia e do estado. Carlo Giuliani, ragazzo é também o título do filme de Francesca Comencini, que combina imagens do último dia de vida de Carlo com a narrativa de sua mãe, Haidi Gaggio. Ragazzo, enfim, é o modo como tantos dos narradores definem a si mesmos e aos outros participantes do movimento: "supostos black block, jovens vestidos de preto... lembro principalmente duas moças que teriam cerca de dezessete anos, que choravam muito... Outra era uma garota que chorava e que teria vinte e um, vinte e dois anos; à época tínhamos todos por aî" (Alberto).

A inclusão dessa auto-designação sugere que, mais além do dado demográfico, a identidade do movimento é construída a partir do grupo de idade que debuta politicamente em Gênova, entre adolescência e primeira juventude: "se alguém estava em Gênova entre os dias 18 e 19 possuía verdadeiramente o senso de uma geração que veio ali com muita raiva, mas absolutamente sem qualquer intenção de destruir. Era gente que estava determinada a ultrapassar a zona vermelha, mas não desejava fazer um massacre. Tudo isso, mas também isso fez entender a esta geração que é necessário dar um passo à frente na capacidade de organização e de construção do percurso" (Alessio Aringoli).

Alessio Aringoli usa também outro termo recorrente nesta narrativa: geração. De um lado, geração é um conceito unificador no plano transnacional aplicado a um movimento que se percebe em escala internacional ("uma verdadeira ruptura da juventude italiana e européia, internacional, dos países industrializados em um mundo globalizado" Vittorio); por outro lado, o conceito de geração atravessa e articula esperiências e subjetividades diferentes, no interior da mesma situação ("Gênova não marcou apenas a nossa geração, assinalou um momento histórico e, assim, várias gerações; o movimento é também um movimento diversificado, não é composto só de jovens". Emanuele).

Danilo Corradi. De uma parte, foi a explosão de uma geração que nunca havia feito política; de outra parte, foi a explosão de uma geração que havia feito política pensando que não conseguiria mudar nada e que, assim, pode reconstruir a utopia possível. Porém, é

to quanto aquele rapaz que matou Giuliani, tinham todos vinte anos nesta situação de merda" (Anna Carone). 
uma geração que, um dia depois de Gênova, ficou dividida e vai realizar muitas coisas diferentes; explodirá de maneiras diversas e terá problemas muito diversos daqueles que tem hoje. Mas demonstrou também uma outra coisa, demonstrou que a radicalidade desta geração não é passageira, neste sentido se pode reportar ao que aconteceu em 1968, eu penso assim.

Alessio Aringoli. Todos os portavozes da antiglobalização tendiam a pensar que, de qualquer modo, era melhor inventar coisas... A nossa geração não é de inventar coisas - e não é porque somos moderados. Lembro que Bernocchi dizia, em assembléia, que não era possível escandalizar-se porque se queima uma bandeira americana: não é isso, porque a nossa geração não concebe o discurso de inventar coisas, mas quer instruir-se; é em parte confiante em si mesma, não viveu todo o percurso de traição que sucedeu 1945, com o Partido Comunista Italiano indo cada vez mais para a direita. De qualquer modo, temos a sensação de partir da estaca zero, e quando se parte do zero não se aceita queimar a bandeira americana, porque não percebes isso como um gesto de consenso naquele momento, mas como um gesto ofensivo para com aquela gente morta e não te reconheces naquele gesto e não desejas estar no imaginário que aquele gesto pode criar; desejas construir um outro imaginário. Estou seguro que também no nível do imaginário, em qualquer transmissão, se houvessem mandado um jovem com quinze anos menos do que Agnoletto, para expor a questão, quem sabe menos corajoso, mas que tivesse dado a explicação de quem éramos, coisa que, segundo eu, apesar da coragem, ninguém conseguiu dar. ${ }^{19}$

\section{A geração do telefone celular}

Antonella Valentini. Eu não estava com o celular que, então, felizmente botei fora. Me libertei daquele droga infernal. Minha mãe tentava me chamar através do celular da minha amiga, logo depois da notícia de Carlo, mas praticamente os celulares não conseguiam linha, porque talvez houvessem feito de maneira que não... e, seja

19 De um outro ponto de vista, a presença destas figuras mais "conhecedoras" para alguns era tranqüilizante; era também a confirmação de que não eram tão diferentes: "A humanidade daquelas pessoas que vês sempre - está bem, Bertinotti, mas também: Frisullo, Agnoletto, que é o portavoz: também foram ouvidos numa assembléia improvisada realizada depois daquela agressão, com a caçada aos manifestantes; ouvi exprimirem a sua humanidade, ouvi, mais além das discussões políticas, entendes que te expressam o drama que está contecendo e o conhecimento que eles têm do drama daquelas pessoas que estão sendo agredidas. Eles têm informações que nós não tínhamos, sobre o que estava acontecendo. Aquilo é também uma coisa que lembro com satisfação (Emanuele Profumi). 
como for, não ligavam e, depois de um tempo, ouvi minha mãe que gritava e que não conseguia ouvir-me. "Antonella! Antonella como estás?" - chorando. Ela tinha quase certeza de que eu estava morta. A voz era, sabe o terror? Estava aterrorizada, evidentemente, porque não me ouvia. Depois procurei tranqüilizá-la - "não mãe, não te preocupes, não me aconteceu nada, estou bem, estou aqui com os jornalistas" - e depois que falei com minha mãe, rompi em pranto, um pranto histérico, e não sei quanto durou, penso que ali mesmo rompi em pranto.

Gênova 2001 é talvez o primeiro evento de massa da idade da nova tecnologia. Quase que havia mais filmadoras e máquinas fotográficas do que pessoas, o que faz de Gênova um dos eventos mais minuciosamente documentados da nossa história. Sobretudo, a maioria dos participantes possuía o novo ícone da contemporaneidade: o telefone celular. ${ }^{20}$ Como disse Luca Conte (que trabalhava no centro de imprensa antes que a polícia o destruísse), "a principal fonte de comprovação daquele evento, e esta é a minha impressão pessoal, é a memória digital dos celulares, das vozes, dos números, das mães, das tias, dos irmãos, dos primos, envolvidos em uma pesquisa de informação e de conhecimento, que esclarecem sob o ponto de vista afetivo, mas também sob a tomada de posição e a manifestação da própria indignação".

O celular é um modo pelo qual os jovens permanecem em contato entre eles e um modo pelo qual os pais acompanham o movimento dos filhos. Em Gênova, ambas as funções foram colocadas no nível de massa. De um lado, em Gênova "havia coisas um pouco paralelas, gente que falava no celular com pessoas de outras passeatas, advogados e médicos que circulavam, estavam todos em contato" (Chiara); de outro lado, os celulares que suprimiam a distância entre aqueles que estavam alí e aqueles que estavam distantes - e, sobretudo, entre pais procupados em casa e jovens na rua.

Rossella Marchini. Então, na quinta-feira, recordo que houve uma manifestação de imigrantes que acompanhei através do rádio e depois, à noite, falei com Alicia que estava entusiasmada, porque eram muitos estes imigrantes, porque era uma manifestação alegre, bonita, e Alicia estava contente. Por isso eu estava feliz com a perspectiva de viajar a Gênova, no dia seguinte. A sexta-feira, a sexta, ao invés, foi um dia dramático, porque soube em direta da morte do ra-

20 A Itália é o país europeu com a mais alta concentração de celulares: é de 1 por 10 a relação entre celulares e população; em seguida está a Alemanha com 7,4 e depois todos os outros países. Os dados foram extraídos do jornal La Repubblica, 8 de abril de 2005. 
paz, ouvindo no rádio sobre as famosas praças temáticas ${ }^{21}$ e sobre o assalto à Zona Vermelha, ${ }^{22}$ recordo com terror. Ouvi depois várias vezes aquela gravação na rádio; disseram que alguém fora morto, que havia um morto, sim e não, "aquelas frases, a um certo ponto ouvi dizer que se tratava de uma moça e, naturalmente, sabendo que minha filha estava ali e não conseguindo falar-lhe por telefone, porque não me dera notícia durante aquele dia - de quando em quando havia enviado uma mensagem: tudo okay, fica tranqüila, não estou aqui, não estou...", e depois, seja como for, falava-se de outros feridos, de outras coisas - lembro de ter sentido medo por ela, por todos aqueles jovens. Logo em seguida, à noite, consegui falar-lhe e me disse "Mamma, fica tranqüila que está tudo bem". À noite havia chovido um dilúvio, a barraca estava molhada, enfim, era uma novela. O clima mudara de repente; do seu relato e do que eu ouvia, percebo que tudo havia mudado completamente, e por isso partimos à noite. Decidiram que o ônibus para o qual havíamos feito reserva não viajaria mais; esperamos na estação no meio de muitas pessoas, que se amontoaram naqueles trens e chegamos sábado pela manhã. Porém, naquela situação, mesmo se não tivesse organizado tudo, viajaria a qualquer custo, em suma, era importante estar alí no dia seguinte.

Graças ao rádio e à televisão, mas sobretudo ao celular, o episódio de Gênova estava acontecendo em toda a Itália; o celular era a materialização dos laços emocionais que conectavam Gênova ao resto da Itália e da Europa. Emanuele Profumi conta que ele e seus companheiros conseguiram manter-se longe da polícia, porque o pai de um deles, que acompanhava a situação em casa pela TV, comunicava-lhe por telefone os movimentos da polícia, indicando os lugares seguros da cidade.

Pina Monaco. Era um pouco invejosa deles que podiam estar ali, porque via e eles me contavam pelos celulares que a manifestação era grande, diversificada; minha filha me dizia que havia muitíssimos jovens, inclusive jovens em cadeiras de rodas, havia pessoas da idade do seu pai que, segundo ela, eram velhas. Seja como for, estou arrependida de não ter viajado, porque dei demasiada importância ao medo inconsciente, de um confronto, digamos. Ainda não possuía qualquer notícia desse confronto, porém estava com medo, inçoscientemente. Daí que vivenciei tudo através do contato com eles, acompanhando pela televisão; depois foi aquilo que, a um certo ponto, me perturbou a existência; senti um grande medo quando

21 As pessoas que vieram a Gênova encontravam-se distribuídas em cinco diferentes praças, destinadas a diferentes temas: guerra, meio-ambiente, imigração, etc.

22 Esta é a zona da cidade cercada por policiais e fortificada, cujo acesso esteve proibido para os manifestantes e para todos os cidadãos. 
ouví a notícia de que ocorriam os primeiros confrontos. Chamei o pai de minha filha, que sabia estar angustiado, e que percebí muito nervoso porque estava perdido da filha e de sua amiga, no meio das bombas de gás, do lacrimogênio; ele dizia não ter jamais sentido um cheiro tão estranho e uma sensação tão horrível nos pulmões e na garganta. Naquele momento, eu estava praticamente enlouquecida, porque ele não conseguia encontrá-la; ele sofre de pressão alta e, a um certo ponto, eu não conseguia mais a linha telefônica; depois consegui a linha e ele estava perdendo os sentidos, porque a pressão tinha subido, sob o sol forte, com este bendito gás lacrimogênio; então ele entrou em um beco, onde uma senhora do alto lhe jogou água por cima e assim ele se recuperou. Digamos que, como houvesse sempre conhecido Gênova, começou a caminhar, e finalmente localizou a filha: deu-lhe por telefone a indicação do lugar onde deveriam encontrar-se. Soube depois que justamente ali se encontraram, chorando, etc. O que me contava minha filha, por telefone, me tranqüilizava. O que a impressionou muitíssimo, deixando-a paralisada, assim como a amiga, eram os pancadas que muitos recebiam, que recebia um rapaz que estava em uma cadeira-de-rodas; elas queriam ajudá-lo, entretanto mal conseguiram salvar a própria pele, e minha filha teve sempre essa lembrança assim dramática, deste rapaz.

\section{Pais e filhos em Gênova}

Enrica Bartesaghi. Para mim, Gênova 2001 representa um trágico retorno à realidade; não porque eu vivesse fora do mundo... não me parece, lendo diariamente um par de jornais, em suma, mantendome informada. Sara, minha filha, que então estava com vinte e um anos, me explicou porque havia ido a Gênova e, em boa parte, partilho com ela os motivos que a influenciaram, assim como a muitos outros. Digamos que eu estava um pouco fora da realidade até junho de 2001. Acreditava já ter feito o meu dever quanto a estar na primeira linha das manifestações e que, de qualquer maneira, poder-se-ia ceder espaço aos filhos, permitindo-lhes que seguissem o seu caminho. Por isso não fui a Gênova, um dos motivos era não desejar parecer uma mãe ansiosa, que segue sua filha na primeira manifestação de que participa, mesmo que acompanhasse tudo de casa, junto com meu marido, pelo rádio, televisão, etc.

Como vimos, nem todos os pais haviam ficado em casa. Alguns foram junto com os filhos, como o companheiro de Pina Monaco; outros foram por sua conta, como o prefeito de Monterotondo. Se a identidade do movimento fosse apenas de uma geração, a sua composição não seria tão variada: não acredito que seja um movimento sobretudo de jovens. "Agora me vem à mente Bové, 
que em suma não é jovem, me vem à mente Agnoletto, que jovem não é; não, não creio que seja um movimento de jovens. Acredito que os jovens o levaram avante, o que é uma outra coisa, mas as idéias de Rifkin, e mesmo as de Chomsky que, em síntese, me lembro dele a partir de 1968 - isto é, alguns dos teóricos, digamos, não eram jovens. Aquele de 77, por exemplo, aquele sim foi um movimento de jovens, em grande parte. Este não, este me parece um movimento diversificado, de mulheres, de crianças, de velhos, de freiras" (Esther Koppel). Por outro lado, também os jovens em Gênova estavam conscientes da presença de representantes de outras gerações: "Bateram inclusive no pessoal do Cobas, ${ }^{23}$ encheram de socos aqueles que participavam da passeata, participavam outras pessoas mais velhas, dois, três negros que participavam, veja bem, poderia ser um amigo do meu pai, que também estava no Cobas..." (Emanuele Profumi). Entres os adultos presentes em Gênova, havia personagens políticos, sacerdotes, professores e jornalistas, a maior parte dos participantes da passeata era de imigrantes, e toda uma infra-estrutura de advogados e médicos.

Depois do assassinato de Carlo Giuliani, os DS 24 retiraram-se do protesto ("verificamos com os companheiros que se poderia também ir para o ônibus, mas este foi suspenso e, entre outros, este também resultou num posterior motivo de raiva, de desilusão que, quando se soube claramente o que havia acontecido naquele dia, decidiu-se que os $D S$ não participariam mais da manifestação do dia seguinte" (Ugo Balzametti). Todavia, depois da notícia das agressões, violências e prisões, muitos pais perceberam que era impossível permanecer em casa. E partiram no meio da noite, como a demonstrar a urgência do momento.

Ugo Balzametti. Eu havia decidido não participar. Quando retornei à casa para falar com minha mulher, discutir nossas emoções, medos, preocupações e, sobretudo, dividir a tensão de pensar como nosso filho poderia vivenciar esta dimensão para ele totalmente desconhecida, trágica, sabendo que estava só, mesmo se junto de tantos outros companheiros. Como não estávamos junto dele, explodiu um elemento de proteção, de uma parte, mas também de raiva política, uma mistura explosiva que provavelmente nunca havíamos conhecido. Penso poder também falar por minha mulher. Havíamos conhecido a tensão política durante a fase do terrorismo, naquele mesmo período de '77, mas essa mistura, essa dimensão forte de

23 Cobas é a sigla que designa os Comitati di Base, uma rede de organizações de trabalhadores que contesta os sindicatos tradicionais.

24 Democratici di Sinistra, denominação que substituiu aquela do antigo Partido Comunista. 
emoções, de proteção a um pedaço da própria carne com raiva política, acabou sendo uma coisa só, uma dimensão dificilmente controlável. Por isso, às sete da noite, quando retornei à casa, decidimos embarcar num trem especial para Gênova, que partia à meia-noite.

Assim Gênova é cenário para os percursos de pais e mães, que vão de um lugar a outro da cidade procurando os filhos que não encontram. Antonino Lupi e sua mulher partem à uma e meia da madrugada e percorrem trezentos quilômetros de carro, de Monterotondo a Genova, depois que souberam da prisão do filho:

Ao longo da viagem tentamos várias vezes, por telefone, fazer contato com a delegacia de polícia. De Monterotondo até Gênova fizemos dezenas de telefonemas, obtendo sempre a resposta "chame outro número"; no final, estávamos completamente desanimados quando chegamos à delegacia central de Gênova, onde já nos esperava o advogado do Forum Social. Conosco viera também meu cunhado que, com minha mulher, entrou na delegacia para solicitar alguma notícia sobre o paradeiro do nosso rapaz; precisávamos saber qualquer notícia que fosse sobre ele. Eu permanecera no carro, porque não havia lugar para estacionar, e assisti a chegada de Fini ${ }^{25}$ na delegacia central; assisti a um ir-e-vir de sujeitos vestidos de negro, como dizia Bruno, seriam todos black bloc policiais, e senti instintos homicidas naquele momento. Naquele momento, ainda não se imaginava aquilo de depois sucederia na escola Diaz e que, no meu parecer, evidencia fortemente o envolvimento e a responsabilidade do governo. De qualquer maneira, não foi possível ter qualquer notícia nesta delegacia central; ninguém dava notícias, não existia uma lista dos detidos. Nem ao meio-dia, ou mesmo por volta da uma hora, não havia uma lista com o nome dos detidos. Então o advogado disse: "Levaram muitos para Bolzaneto". Fomos a Bolzaneto; havia um grupo de policiais, e tentamos obter notícias; primeiro responderam de modo grosseiro, mas depois minha mulher conseguiu convencer um dos policiais que disse ter sido o rapaz levado para Alessandria, que uma consulta médica fora realizada e que não revelara nada de preocupante.

Depois de saber notícias da filha, Rossella Marchini e seu marido embarcaram em um dos últimos trens para Gênova e chegaram às seis horas da manhã.

Descemos do trem na estação de Quarto; recordo que era muito cedo e que estava tudo fechado. Porém, mesmo sendo uma hora estranha para andar na rua, talvez fossem seis da manhã, tratamos de

25 Refere-se a Gianfranco Fini, Vice-Primeiro-Ministro e Ministro das Relações Exteriores da Itália, líder do partido da Aliança Nacional, que faz parte da coligação de direita que apóia Silvio Berlusconi. 
procurar um bar para tomar o café da manhã, arranjar qualquer coisa para comer. Caminhamos muito e tudo estava fechado, continuava fechado mesmo depois - às oito, às nove horas. Era uma cidade deserta na qual viam-se só jovens com seus sacos de dormir, pessoas que haviam desembarcado do trem; era uma cidade totalmente fantasma, porque viam-se caixas automáticas e vitrines quebradas, carros arrombados e tudo o mais fechado, não havia nada, nem mesmo um sinal de vida que fosse da própria cidade. Só nós, os invasores.

Naquele momento, isto foi a coisa que mais me impressionou, porque quando se chega a uma cidade nunca há este aspecto, nem mesmo no dia de Ferragosto, ${ }^{26}$ não é? E fomos ao Carlini, para procurar minha filha, para falar-lhe, vê-la e, assim, tranqüilizar-me. Encontramos o estádio cheio, cheio de jovens, de barracas, de sacos de dormir, de gente que tratava ferimentos, decorrentes do dilúvio que precipitara à noite ou do tumulto na manifestação do dia anterior. $\mathrm{E}$ o que fiz depois? Continuamos a caminhar, praticamente caminhamos pela cidade com outros amigos, sempre a procurar qualquer coisa para comer e entramos no hospital, com ar indiferente, e nos enfiamos no bar do hospital e alí tomamos o café da manhã. Não conseguimos entrar pela porta principal, porque alí estavam os feridos da véspera, e por isso não permitiam a entrada de visitantes, não permitiam que entrasse ninguém, mesmo que não apresentássemos um aspecto jovem. Então entramos por trás e por ali conseguimos alcançar o bar e engolir um cornetto, tomar finalmente um cappuccino, ${ }^{27}$ ir ao banheiro. Isto, digamos, facilitou a entrada para outros, para outros rapazes que viram toda aquela coisa, mas eles depois não conseguiram mais entrar, porque o pessoal do hospital deu-se conta de que era gente de fora que usava o bar e o banheiro, único aberto em toda a cidade e, assim, trataram de fechar o hospital e não permitiram que ninguém mais entrasse.

A cidade estava fechada e assustada, mas não faltam narrativas de solidariedade e de ajuda (como a senhora que borrifou água no companheiro de Pina Monaco). Por outro lado, a cena em que os adultos abrem caminho para que os jovens pudessem usar o banheiro sugere um papel que não estava previsto para esses adultos: dar alívio e proteção a jovens extraviados e feridos.

26 O feriado de ferragosto é em 15 de agosto e corresponde à Nossa Senhora da Assunção. Ao tempo dos romanos, ferragosto correspondia a todo o mês de agosto, mês de festas, despedida do verão, instituído pelo Imperador Augusto. A palavra ferragostoé hoje sinônimo de férias, veraneio, quando as cidades ficam vazias.

27 Cornetto, espécie de pãozinho assado, feito com massa folhada, em forma de um corno; cappuccino é café com leite e com creme. Ambos, compõem a habitual primeira refeição do dia na Itália. 
Pina Monaco. Como ali estava conosco uma senhora da Rifondazione ${ }^{28}$ com cerca de setenta anos, que se sentia mal e que estava precisando ir ao banheiro, umas pessoas permitiram que entrasse na sua casa, deram-lhe algo para beber e deixaram-na usar o banheiro; também naquela casa nós enxaguamos o rosto e depois ficamos perto do portão, não fomos além, porque não estaríamos seguros. Estivemos por ali cerca de uma hora; depois, devagar, colocamos o nariz para fora, procurando chegar à estação. Queríamos voltar à estação para retornar à nossa casa, alcançar logo o trem. Saímos e começamos a caminhar bem devagar. Uma coisa simpática que lembro é o encontro com uma moça amedrontada, muito jovem, que poderia ter a idade de minha filha e que estava colada nos nossos calcanhares. Perguntava: "posso andar com vocês, posso andar com vocês, aonde vão? Eu devo ir ao Carlini". Eu lhe respondi: "olha, nós vamos em outra direção, para a estação". Então ela telefonou e disse: "mãe, fica tranqüila, consegui emprestada uma camiseta laranja, porque estava vestida de preto, logo hoje, e depois fica tranqüila, porque estou com duas pessoas mais velhas e parecemos uma família, assim não devo estar dando na vista". Eu me sentia aflita com a idéia que alguém pudesse ficar seguro só pelo fato de encontrar-se comigo, quando eu mesma estava em pânico, sem qualquer notícia de minha filha. Os telefones não funcionavam mais; eu tentava chamá-la e ela provavelmente me chamava, e eu não recebia o chamado; já sabia sobre a violência pelas pessoas que encontrava na rua, pessoas que haviam escapado e que presenciaram confrontos violentíssimos, na parte dianteira da passeata.

Por toda Gênova e mais longe ainda, as pessoas se procuram, os pais procuram os filhos: "Tudo isto eu e seu pai, os amigos e parentes, ficamos sabendo alguns dias depois; porque, para nós, ela desaparecera em Gênova de sábado à tarde até segunda-feira, por volta do meio-dia, quando descobrimos que estava na prisão de Vercelli" (Enrica Bartesaghi). Família, advogados, jornalistas giravam em torno da prisão de Alessandria, procurando comunicação com os filhos presos e esperando sua libertação.

Antonino Lupi. Em Gênova, com o advogado, fizemos contato com outro colega seu, de Alessandria; fomos à prisão de Alessandria, onde chegou este advogado, cerca de duas horas depois. Ele pôde encontrar Bruno brevemente. Havíamos dado a ele uma carta para ser entregue a Bruno, na qual procurávamos deixá-lo mais tranqüilo, dizendo que estávamos perto dele, que estávamos fazendo de tudo para que logo terminasse aquele pesadelo.

28 Partido della Refondazione Comunista, fundado depois que o Partido Comunista mudou de nome, passando a chamar-se Democrático de Esquerda, renunciando portanto a chamar-se "comunista". 
A prisão de Alessandria está localizada em terreno plano e é exposta ao sol, fora da zona urbana; além de nós, como visitantes, lá estava somente uma pessoa, que depois reconheci como o advogado Pisapia, que, como parlamentar, fora visitar os rapazes; ele era também conselheiro regional pela Rifondazione Comunista do Piemonte. $\mathrm{O}$ advogado falou com Bruno e, quando saiu, disse "Bruno teve sorte, porque para ele foi menos ruim do que para os outros, talvez pelo fato de ter permanecido muito tranqüillo, de ter permanecido sempre calmo; Bruno de algum modo esquivou-se, evitando danos maiores". Pisapia, saindo, disse que recolhera testumunhos tremendos e que estes seriam levados à sede do partido, porque era vergonhoso.

Convencidos de que não havia muito a fazer, visto que os interrogatórios com juízes estavam marcados para dois dias depois, retornamos a Monterotondo; nos preparamos e novamente partimos um dia depois, pensando em assistir ao interrogatório; desejávamos acolher Bruno logo que fosse solto. Chegamos em Alessandria na tarde anterior, e às oito e meia da manhã fomos ver Bruno, o que só conseguimos por volta das nove horas da noite. Ele foi interrogado nas primeiras horas da manhã, talvez, oito e meia, nove, e precisamos esperar cerca de doze horas para que fosse liberado. Fomos os primeiros a chegar, mas depois chegaram outros pais de jovens presos que haviam sido interrogados. Constatamos então que eram jovens parecidos com Bruno, ou seja, pessoas que, por temperamento, não faziam mal. Era o traço característico de todos. Ali estavam os pais de um escoteiro, de um rapazinho que quase havia sido acompanhado por um pároco nesta aventura, havia rapazes espanhóis das brigadas internacionais pela paz, havia professores do Liceu, havia gente de todo o tipo que, seguramente, não eram pessoas agressivas.

À medida que os rapazes saíam, percebemos o tratamento que lhes dispensaram. Particularmente impressionou-me um professor que lecionava filosofia em Catanzaro, pessoa de cerca de cinqüenta anos, cheio de marcas, aterrorizado pela experiência recente... Fora da prisão encontravam-se jornalistas, que procuravam entrevistá-lo, mas esta pessoa estava de tal maneira amedrontada que era incapaz de pronunciar palavra, e procurava na verdade escapar; a única coisa que disse foi: "Eu não estive na manifestação, estava mal. Sentia calafrios e ânsia de vômito e, por isso, fiquei no acampamento do Cobas, e foi ali que me pegaram". Na verdade, os agressores faziam parte de um grupo, de uma missione squadrista. ${ }^{29}$ Três rapazes espanhós, das brigadas internacionais de paz e um rapaz suíço me contaram suas sofridas experiências; são pessoas incapazes de cometer violência, visto que colocam o próprio corpo em defesa de pessoas

29 Grupo que pratica ações violentas, nos moldes daqueles que eram freqüentes nos anos vinte, as chamadas squadre fasciste. 
que precisam ser defendidas; contaram sobre um rapaz sírio, um homem sírio com uma prótese de madeira na perna, que não conseguia manter-se em pé por todo o tempo necessário e, por isso, de quando em quando caía e obrigavam-no a levantar à força, a golpes de cacetete dos policiais que estavam presentes. Este foi o testemunho colhido praticamente de todas as pessoas que saíram e que, evidentemente, deixaram todos impressionados.

Depois saiu Bruno, por volta das oito e meia, nove da noite e, considerando o que passou, estava melhor do que imáginávamos que pudesse estar.

\section{Retorno para casa}

Alberto. Partimos e eu retornei a Paola, na Calábria; cheguei às oito da manhã. Telefonei para casa para dizer: "olha que cheguei...", à época eu possuía um celular, mas a bateria estava sempre descarregada. Mais de quatro horas não durava a bateria do meu telefone e, por isso, ele estivera desligado das sete da noite de sábado até o outro dia pela manhã. Liguei para casa, de uma cabine, e atendeu minha mãe alarmadíssima: "Acreditava que ficasses em Gênova, prenderam um monte de pessoas, espancaram...", e ela pensava que eu... no último telefonema disse-lhe que dormiria em Gênova, no lugar onde estavam todos. Me referia mais ou menos ao Carlini ou ao hospital psiquiátrico, nem mesmo pensava de ir à escola Diaz, porque sinceramente não sabia o que era essa Diaz. De fato, disse: "olha que eu estou em Gênova, depois volto". E depois, fui convencido pelos outros a ir para a Diaz. Minha família, lá em casa, quando se levantaram de manhã, olharam o telejornal e viram todos esses rapazes machucados, espancados, toda aquela gente, a violência; em casa os meus pensavam que eu estivesse entre estas pessoas. Quando disse que era eu, lembro este telefonema, uma das poucas coisas que recordo com muita lucidez, que realmente sucederam as coisas na Diaz e que eu conseguira voltar.

"A preocupação de minha mulher e também a minha era que essa coisa houvesse deixado problemas de caráter psicológico, e por isso, nos dias següintes, o fizemos encontrar com um psicólogo da $\mathrm{Asl},{ }^{30}$ que tranqüilizou sobre o estado mental e emotivo de Bruno. Havia, contudo, um elemento de preocupação para o psicólogo: Bruno era muito fixado no fato de que, no futuro, não poderia mais participar livremente de manifestações" (Antonino Lupi). Outros ficaram com feridas mais profundas: falam de pesadelos recorrentes, do medo instintivo do barulho dos helicópteros ou da

30 Azienda Sanitaria Locale, ou seja, aos serviços públicos sanitários da localidade. 
farda dos policiais; entretanto, para muitos, Gênova é motivo de participação ainda mais intensa e consciente no movimento; outros participantes foram virtualmente paralisados pelo choque.

Voltando para casa, os jovens sobreviventes de Gênova precisaram defrontar-se com dois problemas interrelacionados: gerenciar o trauma da experiência e compartilhá-lo com a família. "Logo que cheguei, fiquei duas horas no meu quarto" (Antonella Valentini): fechar-se no quarto, no espaço próprio, ou procurar segurança no sono são maneiras de isolar-se, para refletir e para preparar-se para o impacto com aqueles que estiveram ausentes de Gênova e que sabiam somente através das versões distorcidas da mídia.

Também as atitudes dos pais variam, segundo inclinações políticas e grau de envolvimento na experiência dos filhos. Mas todos compartilham uma mistura de sentimento de proteção pelos filhos, que estiveram em perigo, e de ressentimento pela preocupação e pelo medo que lhes foi causada. Uma imagem recorrente de sentimento de proteção é aquela das mães que velam o sono das filhas:

Pina Monaco. Me senti próprio mãe e leoa. Não parecia verdade que minha filha estivesse aqui depois do que contaram e que ela contou, falando inclusive de amigos seus que estavam na Diaz e que conseguiram ir embora antes que acontecesse o drama; de um amigo, de uma amiga sua que havia cuspido sangue. Por isso, no primeiro dia que minha filha estava em casa, tive esta atitude de mãe, andava ao seu quarto e olhava na sua cama para ver como dormia. Posso parecer um pouco patética e ridícula, mas penso no que poderia ter acontecido, no que aconteceu a Carlo, que poderia ter sucedido a qualquer outro rapaz, que poderia ter sucedido com a minha filha.

Brunella Pinto. Tenho a impressão de que o retorno a Roma foi a parte mais difícil de todo o episódio de Gênova: encontrei meu pai com a pressão alta, minha mãe que, em certos momentos, quase morria com ataques de asma; na primeira noite que estava em Roma logo adormeci, porque já eram três noites que não dormia. Sentia durante o sono a presença de minha mãe, minha mãe que velava por mim; enquanto dormia, me dei conta de tantas coisas. Quando me acordei... precisava enfrentar, porque, seja como for, os meus pais acabavam sendo o meu primeiro confronto com o mundo.

Depois chega o momento de levantar e sair do quarto. Determinados pais são politicamente hostis, mas deixam que o afeto obtenha vantagem sobre a ideologia: "Contei o acontecido e alí estava meu pai que, apesar de pensar o contrário, visto que um monte de vezes brigamos, e diz coisas que talvez não pense; seja 
como for, estava muito abalado. Se nunca me havia telefonado, na realidade estava preocupado e buscava informar-se com os outros. Houve posteriormente um momento de conflito em que melhor comprendi que estava abalado. Depois me largou de mão" (Emanuele). Outras vezes o conflito é imediato: ideologia e ansiedade resultam em ressentimento agressivo.

Antonella Valentini. Os meus pais são católicos, são muito catrólicos, meu pai votava com o DC; $;^{31}$ minha mãe é filha de um carabiniere $^{32}$, além do mais, ele é monarquista, e por isso sou absolutamente contrária; na verdade, fui a Gênova escondida de meu pai e disse à minha mãe: "Eu vou, mesmo que ele se meta na frente da porta. Devo ir". E então minha mãe decidiu não dizer-lhe nada, porém quando houve... em suma, minha mãe ficou para morrer diante da televisão, quando viu e ouviu, em telejornal, que uma moça fora morta. Por isso minha mãe estava morrendo diante...

E não podia dizer nada para o meu pai que, entretanto, entendeu. "Sei muito bem que a tua filha está em Gênova e agora já podes me dizer" - porque, sabes, meu pai também estava bastante tenso. Me viu sair com a mochila e disse-lhe que ia estudar para o exame na casa de uma amiga, coisa bastante... e daí parti e, de fato, quando voltei, meu pai não falou, só depois falamos abertamente, porque à minha volta... está bem, esta é uma história feia: quando voltamos, um primo meu, do sul, estava lá em casa para jantar e eu não devia dizer que tinha ido a Gênova, porque meus pais não queriam que os seus parentes de lá soubessem e, por isso, precisei fingir que nada havia acontecido. Porém, apenas chegando em casa, fiquei duas horas no meu quarto e depois fui comer; via-se na TV as cenas de Gênova, e meu primo começou a elogiar os policiais, recomendando: "batam, batam". Assim levantei e meu primo compreendeu que eu fora a Gênova. No dia seguinte, meu pai começou a fazer a defesa de Berlusconi e de Scajola. ${ }^{33}$ Não compreendo o motivo, mas foi bastante difícil, isto é, o fato de que eles não tenham compreendido. Fui um pouco agredida por eles. Quando voltei para casa, meu pai continuava a não me dar razão, dizendo que haviam feito bem e que deviam matar a todos, como se eu não tivesse estado em Gênova. Para mim era muito duro lembrar Gênova, também porque não tive, nem mesmo em casa, alguém que me dissesse: "Sim, tens razão pelo menos de estar amedrontada".

Partido da Democracia Cristã, partido tradicional de direita.

2 Membro da força militar italiana de polícia.

33 Silvio Berlusconi foi presidente do Conselho de Ministros de 1994 a 1996 e continua presidente desde 2001; Silvio Scajola foi responsável pela organização do partido de Berlusconi, o Forza Italia. 
Em última análise, e por tudo, criou-se um confronto ambivalente, no qual a mistura de orgulho e de preocupação experimentada no momento da partida se transformava em nova mistura de proteção com ressentimento.

Brunella Pinto. Sempre foi assim comigo, desde que nascí e... ela, a primeira coisa... ela teve a reação de quem ficou em casa, assistindo os telejornais: "vocês provocaram, aquele tinha até um extintor!"... clássicas reações que até agora tanta gente quer defender. "Sim, mas vocês! Sim, sim, foram um pouco violentos, mas vocês estavam lá provocando, atirando pedras, vocês"... e houve este conflito fortíssimo de gerações com minha mãe, terminado...., porque este é um parêntese, falo sempre com as minhas amigas... há sempre aquele pathos nas famílias meridionais, não? Nunca se pode enfrentar com tranqüilidade uma discussão... sempre deve ter alguém que desmaia, tem um ataque de asma, alguém que berra. Ahhhhh, este é mesmo o pathos do sul, teatro grego, conforme eu, que vem mesmo com o DNA. Depois, principalmente com minha mãe, isso acontece, e por isso lembro que, depois de gritos e choro... essa discussão, eu procurava falar, porque depois... de conseguir que entendessem, de botar para fora, desejava jogar-lhe na cara aquilo que me tinha acontecido e ela me jogava na cara o que lhe havia acontecido enquanto estava em casa, em Roma. Depois me lembro que, exausta, fui para o meu quarto e ouvi do quarto sua conversa no telefone com um amigo. Dizia: "Olha que foi a polícia que provocou, olha que... olha que eles estavam desarmados, eles não fizeram nada, olha que...", em seguida minha mãe assumia o meu ponto de vista e lembro de ter rompido, sim..., em lágrimas naquele momento, porque disse a mim mesmo: são essas coisas que transformam o mundo.

O episódio de Gênova acontecera no início do verão e, assim, a discussão do episódio estava apenas recomeçando, depois da interrupção pelas férias de agosto, quando ocorre o atentado de 11 de setembro, que praticamente anula o resto. Os jovens que estiveram em Gênova calam-se, porque era como se o seu trauma se transformasse em algo irrelevante: "Aconteceu o 11 de setembro pouco depois de Gênova - como foi vivenciado por quem estivera em Gênova? Faziam um pouco a comparação entre terroristas e aqueles que não queriam a globalização, como se fosse a mesma coisa, por isso quem havia estado em Gênova não conseguia nem mesmo explicar o que lhe havia acontecido" (Emanuele); "Quando acontece um problema, de qualquer forma se enfrenta, mas depois se deixa de lado por outro problema que aparece. Na Sapienza ${ }^{34}$ vi um painel de fotografias com fotos do Carlini [estádio], dos imi-

34 Universidade de Roma. 
grantes, e depois soube que aquele painel desapareceu, quando houve a tragédia de 11 de setembro. Me parece que não é justo deixar de lado, entre aspas, os velhos problemas" (Anna Carone); "A maioria que governa, com um golpe, fez com que fosse encerrada a comissão de inquérito sobre Gênova, em conseqüência do 11 de setembro. Esse encerramento saiu como notícia na página 12 de todos os maiores jornais, quando até 10 de setembro a comissão estava na primeira página. Se tivessem feito isso primeiro, teria estourado um escândalo; mas construía-se um outro espetáculo que estava nas primeiras onze páginas, assim como nos primeiros vinte minutos do telejornal" (Alessio Aringoli).

Andrea Pagnani. O 11 de setembro colocou-nos uma mordaça, desaparecemos com aqueles que eram os assuntos... Começava-se a falar amplamente de globalização; começava a circular um novo tema de discussão no âmbito da sociedade civil. Depois aconteceu o 11 de setembro e, em seguida, irrompeu a guerra; começou essencialmente a guerra que é como um moedor da carne por quem passa por ela, mas é também um moedor de carne para a vida social, no interior de uma dialética política para os países que não vivem esta guerra. Por isso pode-se dizer que o nosso protagonismo desapareceu, passamos ao segundo plano - bem satisfeitos eles de fazer passar o assunto ao segundo plano, porque ele necessita uma discussão interna ampla no país e claro que, se há a guerra, acaba-se dizendo: "depois pensamos na globalização". Com essa discussão nova, tudo fica mais complicado. Enfim, para a guerra já estamos habituados.

\section{Inverter a tradição}

Os moços ensinaram a todos uma lição.

Pete Seeger

Aquela que me tornei, certamente Carlo me fez tornar.

Haidi Gaggio

Esther Koppel, jornalista alemã que vive em Roma, falando dos seus filhos e de Gênova, diz: "talvez por ser intrometida desejei participar através deles". Os pais da geração de Gênova que passaram por 68 e por 77 haviam invertido o fluxo da tradição entre as gerações: eram os jovens de então que educavam os adultos. Mais tarde, todavia, a geração dos anos 60 e 70 assumira em boa parte o papel de depositários da tradição e da experiência pais, sobreviventes, sábios, fundadores - aqueles que, como diz ainda Esther Koppel, pensavam conseguir ensinar aos mais jovens 
como se organiza um sit-in ${ }^{35}$ ou como se escreve um panfleto, porque era assim que se fazia na sua geração. Ainda mais uma vez, os moços desviaram a direção do olhar, e encontraram os seus pais fechados em si mesmos, iludidos, ingênuos: "parece que é um belíssimo remanescente de 68. Em outras palavras é comovente; do meu ponto de vista é mesmo comovente o pensamento do meu pai, que pensa como se estivesse em 68. Não que seja imaturo, absolutamente; mas tem só ideais belíssimos. Eu para algumas coisas agora... não espero mais nada. Não sei, vejo com outros olhos" (Brunella Pinto).

Sobre muitos aspectos, Gênova foi um momento em que os adultos seguiram o rasto dos mais jovens. Ao menos da parte da geração dos anos 60 e 70, o empenho dos seus filhos e a violência de que foram vítimas representaram um estímulo para recomeçar uma prática política na primeira pessoa. Como disse Haidi Gaggio, mãe de Carlo Giuliani: "São dois anos que percorro a Itália e são dois anos que continuo a encontrar pessoas que me dizem aquilo que na realidade eu fiz: estava retirada à vida privada e com Gênova descobri que não se deve retirar-se à vida privada".

De um lado, como vimos, Gênova deixou evidente que a violência do estado e a brutalidade policial não são coisas do passado, e que mesmo o fascismo não é somente um fato histórico. Em certo sentido, foi como ter sido brutalmente jogado para trás no tempo; mas em outro sentido, representou um impulso para uma situação completamente nova.

Danilo Corradi. Com freqüência, naqueles dias e também depois, dizíamos entre nós: "a história acelera-se". Era uma forma de dizer para quem, durante tantos anos, sentiu-se um pouco como resíduo da história, sendo chamado de comunista quando ser comunista já era um pouco fora de moda; quando continuar a fazer o movimento estudantil parecia uma simples repetição daquilo que os pais, as mães, os avós já haviam feito. Ao invés, em Gênova, apenas desembarcamos, sentimos que havia a compreensão e a conviç̧ão, por parte de todos, de ter ingressado num movimento novo. Acredito que foi um processo de compreensão coletiva de uma geração que até agora só havia lido sobre essas coisas nos livros e que jamais se encontrara em uma situação do gênero, digamos. Foi a explosão de uma geração que jamais havia feito política e, de outra parte, a explosão de uma geração que havia feito política pensando de andar no vazio e que, a partir dali, começou a reconstruir a utopia possível.

35 Forma de resistência passiva, quando os manifestantes permanecem sentados e recusando-se a movimentar-se. 
Certo, o movimento é complexo e heterôgeneo; velhas práticas e atitudes coexistem com o novo que, às vezes, as coisas velhas arriscam sufocar. Mas velhos ritos, como as bandeiras queimadas, ou a violência como valor por si só, não servem mais à nova radicalidade; o mesmo acontece quando são repropostosos líderes autodenominados ou os líderes assim considerados a partir da mídia. Em Gênova criou-se um estado de ânimo diferente: "eu lembro de ter visto na televisão este acampamento no meio do barro, sim, recordo bem, com todos aqueles rostos de barbas longas, com olhos cansados e felizes. Isto é, lembro daqueles rapazinhos, não sei como chamá-los de outra forma, que dormiam entre doze em uma barraca e me deixavam feliz, isto é, me passavam ternura, porque podiam muito bem ser os meus filhos. Aquilo que sempre me impressionou foi a propensão ao diálogo, muito maior do que a nossa; isto é, falar com as pessoas, viver realmente a nãoviolência interiormente, isto é, procurando não subjugar o outro" (Esther Koppel).

"Podiam ser os meus filhos". Admiração, ternura, disponibilidade para aprender com os mais jovens não eliminam o fato de que, seja como for, estes são pais. Carlo Giuliani poderia ter sido "um de nós" para os jovens, mas "poderia ter sido meu filho" para os adultos, que olham seus filhos como se, de verdade, pudessem ser Carlo - tanto mais porque, no primeiro momento, tantos pensaram de verdade que o fosse.

Stefania. No dia seguinte aconteceu aquilo que aconteceu, o fato de Giuliani e para mim foi terrível; acompanhei pela televisão e fiquei um dia inteiro a assistir televisão, a olhar a televisão sem falar e lembro que nem mesmo comi.

D.: No teu ponto de vista, porque esta reação? Sabes explicar?

Stefania. O que posso dizer? Todavia porque sou mãe e isto me atingiu de maneira terrível; lembro que também meu filho não me dizia nada e estávamos ali a olhar, aniquilados, isto sim. Aniquilados, posso dizer isto: eu fiquei um dia inteiro diante da televisão sem falar, sem dizer nada e quando meu filho, a um certo momento, me disse qualquer coisa e ficamos juntos, sentados diante da televisão, assim um ao lado do outro, foi realmente um momento terrível e, depois, outro momento terrível foi quando houve o ataque... foram na verdade dias terríveis e depois ver esses pais, isto é... recordo ainda estes momentos em casa, eu não fazia nada, não pensava em mais nada.

Desde o primeiro momento, foram muitos a identificar-se com os pais de Carlo Giuliani - que, não por acaso, são as duas vozes mais eloqüentes depois do episódio de Gênova. Depois que 
a mídia e a polícia haviam procurado apresentar Carlo como um vagabundo, um tipo de menor delinqüente, foi seu pai Giuliano Giuliani a tomar conta da palavra para restabelecer a verdade. Haidi Gaggio, sua mãe, menos visível no primeiro momento, acabou por despertar profundamente o sentimento de muitíssimas pessoas:

Rossella Marchini. Se penso nos pais de Carlo Giuliani, logo me vem em mente a mãe, ela me vem em mente porque participou na primeira pessoa de tantas coisas, vi também um documentário que fez [Francesca] Comencini e a entrevista feita com esta mãe lúcida, sofrida, que reconstruiu as últimas horas do seu filho com tanta lucidez...

Pina Monaco. Começo pela mãe. A mãe, penso sempre que, quando acontecem estas coisas, seja as que dizem respeito à política em geral, seja as que dizem respeito, digamos, a diversas mortes, eu admiro muitíssimo as pessoas que vivenciam a dor em silêncio. Penso sempre comigo mesma: se devesse por desgraça acontecer alguma coisa a uma pessoa querida, eu não teria nenhuma vontade de comunicar os meus... demonstrar as minhas manifestações de dor. Por isso, digamos, tive grande respeito pela mãe, porque permaneceu fechada na sua dor, porque penso que a morte de um filho seja a coisa mais dolorosa para uma mãe.

Haidi Gaggio não sofreu em silêncio, mas jamais levantou a voz. Foi capaz de exprimir a sua dor e a sua perda em linguagem que o novo movimento podia compreender e compartilhar. Longe do palco da mídia, foi mais profunda, assumindo um papel materno para o movimento, oferecendo aos jovens uma voz adulta capaz de articular os sentimentos destes jovens. Em 2004, fizemos uma longa entrevista. A lembrança de Carlo permeava todo o diálogo, mas no centro estava a história desta mãe, a história da sua vida. és?

Sandro Portelli. De onde vens? Como te tornaste a pessoa que

Haidi Gaggio. Aquela que me tornei devo a Carlo, certamente. Sou filha da burguesia suiça, da alta burguesia suíça, por parte de mãe, e do povo veneziano por parte de pai. Por isso sou uma estranha mistura e talvez graças a essas diferentes raízes sempre me senti cidadã do mundo, nunca tive um conceito mais estreito de pátria.

Nasci em 11 de maio de 44, sou uma filha da guerra; os meus pais já tinham três filhos e não haviam planejado ter uma quarta. Passei os meus primeiros meses de vida em uma igreginha desconsagrada, no Vêneto, para escapar dos bombardeios. 
"Carlo teve uma tia que não conheceu, porque morreu antes que ele viesse ao mundo, mesmo antes que eu conhecesse o pai de Carlo, e esta tia atualmente é considerada na Grécia uma heroína da resistência: Elena Angeloni Gaggio. Por isso minha filha tem o nome de Elena. Na Grécia eram os anos da ditadura dos coronéis, saídos do poder um pouco antes, com uma declaração em que afirmavam que o povo grego era um povo feliz, graças ao regime. Foi organizado um cruel atentado e uma bomba deveria explodir diante da embaixada norte-americana que, em Atenas, estava localizada em zona absolutamente isolada; deveria explodir no final do horário de trabalho dos escritórios da embaixada. Explodiu antes. Elena se encontrava ali, chamada pela Resistência, ela e um rapaz cipriota, com passaportes suecos. Estavam como turistas, já com as passagens de avião que os levaria à Suécia. De fato, eu acreditava que já havia contribuído bastante, porque Elena, além de ser a mãe do meu sobrinho, era também minha companheira."

"Os meus filhos cresceram comigo que lhes cantava canções de Resistência, de trabalho, canções de amor e de morte para adormecê-los. Cresceram comigo que assobio algumas árias de Mozart enquanto cozinho, cresceram comigo que faço a limpeza da casa com o rádio sintonizado sempre na estação número três, ${ }^{36}$ que, em tempos passados, era melhor do que hoje, apesar de hoje defender-se de todos os modos possíveis. Uma vez escrevi uma coisa, porque estava verdadeiramente perturbada pelas ofensas que me causavam as transmissões de televisão, os jornais, os livros escritos sobre Carlo. Então, enviei um artigo a diversos jornais e me telefonou a diretora da RAI Tre e me pediu: "senhora, quero saber se nós, de alguma maneira, a ofendemos". Não lembro nem mesmo o nome, sei que era uma mulher e sei que lhe disse: "olhe, infelizmente não consigo mais escutar o rádio, mas, se os da RAI Tre são sempre os mesmos, seguramente não ofenderam ninguém". Existem muitos pseudo-intelectuais que escrevem para encher páginas e vender e, então, as fotos de Carlo, as histórias de Carlo podem servir para fazer dinheiro. A minha vida até 20 de julho foi uma e, depois de 20 de julho, transformou-se numa vida completamente diversa."

"[O advogado] Giuliano Pisapia, de início, me propôs fazer alguma coisa para restituir a dignidade a Carlo, porque fora esquartejado pelos jornais, etc. Eu não sentia esta necessidade de restituir dignidade a Carlo: sentia a necessidade de reconstruir a

36 Entre as emissoras de rádio, a de número três é considerada aquela que está politicamente mais à esquerda, assim como o canal de televisão Rai Tre. 
verdade. E ainda não consegui. Inicialmente [Giuliano Giuliani - o pai de Carlo e eu] nos movimentamos por dois caminhos completamente diversos: ele sofreu o impacto da televisão, da mídia; eu fugi desta com cuidado. E depois, estando em contato com vários participantes do movimento, um dia fui empurrada, mas, na verdade, empurrada fisicamente, porque mal me mantinha em pé diante de um microfone, em Florença; e aquela acabou sendo a minha segunda profissão: andar por aí a falar. Depois, ao longo deste percurso, encontrei todos os outros filhos, todos os outros filhos assassinados nestes últimos cinqüenta anos. É isso aí, eu me esquecia de dizer que a minha primeira manifestação foi por Giovanni Ardizzone [assassinado pela polícia de Milão, em 1960], e eu não pertencia ainda ao PCI. ${ }^{37} \mathrm{O}$ que aprendi, andando pela Itália, é que não é verdade que deixaram há vinte anos de matar impunemente; continuaram a matar, mas nas delegacias, nas prisões, nos cárceres, não nas manifestações, não em público".

Tenho toda uma vida trabalhando em escola, mas com crianças; e sempre pensei que não se pode jamais deixar de pensar, de lembrar, de procurar buscar em nós a criança que fomos para poder, de verdade, ter uma relação com as crianças. As relações que mantinha com os jovens eram muito limitadas: os amigos de Elena, os amigos de Carlo, os filhos dos meus amigos. Depois sou também uma mãe que não desejava ser invasiva, sabe... Por isso a relação com os jovens foi toda uma descoberta. Atualmente tenho uma relação privilegiada, porque aonde vou encontro jovens de um determinado tipo e os encontro enquanto mãe de Carlo e por isso não posso dizer que conheço os jovens: eu conheço aqueles jovens hoje.

A relação com os jovens em geral não é muito profunda, porque viajo como um pombo-correio. Mas com alguns, sim, e em vários lugares: jovens toscanos, sicilianos, porque nos encontramos mais vezes, vieram mais vezes a Gênova. Recordo uma maravilhosa chegada em Senigallia, na região do Marche. Eu nunca pergunto quem são as pessoas que me convidam, não tenho preconceito de nenhum tipo, e por isso cada vez tenho uma surpresa quando chego. Naquela vez, quando descí do trem, havia uns vinte rapazes e moças que me esperavam, eram eles que me haviam convidado. Estupendo. Continuamos a nos escrever. Em Gênova sim, há algumas relações mais profundas.

Espero que os jovens de hoje não rejeitem os partidos políticos, como fizemos nós. Mas é fato que há também aqueles que procuram partidarizar o movimento e isso seria um verdadeiro pecado. Eu me recuso hoje a inscrever-me, ter uma carteira de partido, nem mesmo que me amarrassem. Me recuso, um pouco porque aprendi com Car-

37 Partido Comunista Italiano. 
lo. Carlo esteve por dois anos inscrito nos jovens comunistas e, depois, ... naturalmente pelas grandes brigas com o pai, acabou saindo. Seja como for, tenho relações com os jovens comunistas, tenho relações com estes rebeldes, e vejo que entre eles também estão divididos, que também os rebeldes estão divididos entre eles e isto é um desastre, melhor dizendo, este é próprio desastre. Até que não aprendam por eles mesmos, porque certamente não podemos ensinar-lhes, logo nós que temos cometido mais erros do que eles... com freqüência me perguntam: "como mãe de Carlo, o que deseja dizer aos jovens, o que deseja ensinar-lhes?" Respondo sempre: "nada, são melhores do que eu".

Entrevistas com (nome, profissão, data da entrevista, intrevistadora/intrevistador - alguns sobrenomes não são indicados, por solicitação dos entrevistados):

Alberto, estudante; 1.10.2004, Susanna Trifiletti.

Alessio Aringoli, 1978, estudante; 28.6.2002, Susanna Trifiletti.

Andrea Pagnani, 1970, doutorando em Física; 30.5.2002, Lorenza Parisi.

Anna Carone, estudante; 18.6.2002, Susanna Trifiletti.

Antonella Valentini, 1982, estudante; 28.5.2002, Lorenza Parisi.

Antonino Lupi, 1947, sindaco di Monterotondo; 20.11.2004, Sandro Portelli.

Arianna Lodeserto, 1982, estudante; 23.6.2002, Susanna Trifiletti.

Brunella Pinto, 1981, estudante; 17.7.2002, Sandro Portelli.

Bruno Lupi, 1983, estudante; Monterotondo, 20.11.2004, Sandro Portelli.

Chiara, 1976, diplomada em Filosofia; 20.6.2002, Francesca Pappalardo.

Danilo Corradi, estudante; 22.7.2002, Francesca Pappalardo.

Emanuele Profumi, 1977, estudante; 27.5.2002, Sandro Portelli.

Emanuele, 1977, estudante; 4.12.2003, Lorenza Parisi.

Enrica Bartesaghi, 1954, Comissão Verità e Giustizia per Genova, 29.9.2004, Lalla Di Cerbo.

Esther Koppel, 1950, jornalista; 29.7.2002, Lalla Di Cerbo.

Gianni Di Domenico, 1958, operatore sociale; 14.7.2003, Sandro Portelli.

Haidi Gaggio, 1944, professora da escola elementar; 14.4.1944, Sandro Portelli.

Luca Conte, 1968, trabalha em uma estação livre de rádio; 3.7.2002, Brunella Pinto.

Pina Monaco, 1952, jornalista; 1.9.2002, Lalla Di Cerbo.

Rossella Marchini, 1950, arquiteta; 25.7.2007, Lalla Di Cerbo.

Stefania, 1946, professora da escola elementar; 6.9.2002, Lalla Di Cerbo.

Ugo Balzametti, 1947, empregado; 12.7.2002, Lalla Di Cerbo.

Vittorio, 1940, promotor cultural; 8.7.2002, Lalla Di Cerbo. 